\title{
Future Perspectives of Anatomy in Dental Education: Quo Vadis?
}

\author{
Perspectivas Futuras de la Anatomía en la Educación Dental: ¿Quo Vadis?
}

"Balcioglu, H. A.; ",***Kokten, G. \& *** Guven, Y.

BALCIOGLU, H. A.; KOKTEN, G. \& GUVEN, Y. Future perspectives of anatomy in dental education: Quo vadis? Int. J. Morphol., 28(1):71-73, 2010.

SUMMARY: Anatomists have become familiar with an ongoing debate about the integration of basic sciences into the clinical context or vice versa. Although various educational modalities in dental school curricula and changes in curricular strategies challenge anatomists, the priorities in teaching anatomy and the emergency of presenting fundamental concepts in order to integrate students' basic science skills into the clinic led educators to develop new teaching methods. A search for improved efficiency and impact of the presentation of knowledge to the students in order to foster positive feedback should be one of the major responsibilities of the educators in basic sciences. New gold standards, such as computer-based learning tools and computer-assisted instruction laboratories, may provide trigger points for the perception of the audience in dental faculties. In the light of these considerations, Anatomy Society should rapidly communicate future perspectives.

KEY WORDS: Anatomy; Dental education;Basic sciences.

Future Perspectives of Anatomy in Dental Education: Quo Vadis?The aim of this paper is to suggest future perspectives by examining the role of methodology in the anatomy education that occurs within dental faculties. It reveals how, concerned with the development of anatomical teaching instead of dissection, educational research is nothing other than a modern manifestation of the antiquated tradition of practical anatomy education. Since dissection on human cadavers has been and remains the center of anatomy education, innovative advancements can be involved in the planning of future anatomy education. By all means, Anatomy Society should urgently designate future perspectives while solid problems, such as the shift of universities' interests from basic research to commercial concerns, still exist.

Priorities or utopia? Peer Teaching, that is to say Poor Teaching. Anatomists have become familiar with an ongoing debate about the integration of basic sciences into the clinical context or vice versa. Several reports that indicate the benefits of an integrated curriculum for learning and retention, which emphasize that education is enhanced when it is complemented and learned in the context in which it will later be recalled, have been published (Giffin \& Drake, 2000; Klement et al., 2008; Pabst et al., 1986; Turney 2007). Nonetheless, there have been great debates that concern exactly what should be taught and how.

Although various educational modalities in dental school curricula and changes in curricular strategies challenge anatomists, the priorities in teaching anatomy and the emergency of presenting fundamental concepts in order to integrate the basic science skills of students into the clinic lead the educators to develop teaching methods with a moot creativity. "Moot creativity" refers to some experimental teaching methods that were developed and performed by Wilson et al. (1975), Gregg \& Fuller (1980), Yeager \& Young (1992), Sandra \& Ferguson (1998), Mc Menamin (2008), Philip et al. (2008), in an effort to improve the efficiency and impact of the presentation of knowledge to the students. These "reformist" attempts are no more than do-gooder efforts and do not make sense.

* DDS, PhD; Dept. of Anatomy, Faculty of Dentistry, Istanbul University, Istanbul, Turkey.

** DDS, PhD; Head of the Dept of Anatomy, Chairwoman of the Basic Medical Sciences, Faculty of Dentistry, Istanbul University, Istanbul, Turkey.

${ }^{* * *} \mathrm{PhD}$; Head of the Dept. of Biochemistry, Faculty of Dentistry, Istanbul University, Istanbul, Turkey.

The present paper was presented as a poster presentation at $4^{\text {th }}$ European Meeting of Association of Basic Science Teachers In Dentistry held in London on $8^{\text {th }}-10^{\text {th }}$ September 2008. 
Peer teaching in anatomy laboratories is a poor method with which to more actively engage the student in the learning process. Considering that a cadaver is an extremely "expensive" material in every respect, handing the bistoury to a junior student is not the sole way for him or her to become engaged. There have been several studies that indicate that learning from prosections was more effective, although some studies have found contrary results (Sinclair, 1965; Jones et al., 1978; Nnodim, 1990; Drake, 2007; Azer \& Eizenberg, 2007). Besides, some (Miller et al., 2002) argue that preserved cadavers do not provide realism and that clinical skills are based more on pattern recognition than on anatomical reasoning. This viewpoint might be acceptable if fresh cadavers were more suitable for the student demonstrations. Brueckner \& MacPherson (2004) asserted that peer teaching provides an understanding of students' learning problems, accessing their lives and personalities by using less authoritarian and focusing tactics. This perspective is simply unacceptable. The author's intention is to serve as much more than pedagogues who are simply anatomy teachers.

In an editorial comment, Drake (2002) suggests that educators think outside the boundaries of traditional teaching modalities and become more creative. Then, let us be creative and consider the example of body painting as a creative method. In how many countries is it really possible to paint the bodies of female students when local cultural values are considered? Creativity has side effects.

\section{Technology is good and attractive.}

Interactive computer-based learning tools can engage students with high-resolution images, thought-provoking text, and interactive environments.

If the goal is to introduce interactivity and independence into learning experiences, computer-assisted learning, in combination with teacher-centered instruction of cadaver analysis, may be more beneficial than peer performances. The most important factor here is to provide self-directed learning in order to broaden the student's horizons within the outcomes of cadaver practices in the computer-assisted laboratory. The enhancement of students' communication skills and collaborative and self-directed learning are possible in an area that is more sterile than a dissection room. The students' self-reliance will combine with the knowledge from the teacher-centered instruction of cadaver dissections to consolidate the overall experience. One of the advantages of computer-assisted laboratories is to offer a wide range of learning resources in the curriculum that moves beyond a reliance on textbooks.

The use of plastinated specimens can enable students to learn more efficiently while saving teachers' valuable curricular time. Moreover, in order to establish a more practical link to clinical diagnosis, plastinated specimens of healthy and pathologic organs may be considerably useful instructive materials for the students.

A goal that is very much facilitated by technology and the concept of multiple contextual bases for learning anatomy by means of changes in educational philosophy is to focus on learning, rather than teaching, in order to provide extreme success.

Industrial Science. It is obvious that industrial science is protecting the interests of universities in the face of commercialization in a manner that is detrimental to basic medical education. According to our conception, the strategy of medical commerce fails to yield results in the educational arena, and the ongoing economic crisis threatens to take entire basic medical education down with it.

Shortly. The use of human cadaveric dissection within anatomy education is a superior tool with which to achieve course aims. However, a search for the improvement of efficiency and the impact of the presentation of knowledge to students in order to elicit positive feedback should be one of the major responsibilities of the educators in basic sciences. New gold standards, such as computer-based learning tools and computer-assisted instruction laboratories, may offer trigger points for the perception of the audience in dental faculties. When teacher-centered instruction in cadaver salons is combined with computer-based learning labs, the effective use of plastinization, vast archives of radiologic materials, and clinical anatomy lectures, the result is a thorough curriculum that well prepares students by the semester's end.

Epilogue. Not only does critique seem to be rather confusing, but the severity of its intrinsic vagueness is becoming the foci of reflection among educational discussions. It becomes evident that no form of critique is absolute and that all diversity can, in a way, prevent one from being critical in some sense. In the present article, we focus attention on this vagueness. We consider its identification and question how to address it. To better present the situation, we briefly offer a future perspective and impart some examples. It is to be hoped that various but related methods of providing an anatomy education can combine to become beneficial and reveal common concerns and mutual enhancement.

BALCIOGLU, H. A.; KOKTEN, G. \& GUVEN, Y. Perspectivas futuras de la anatomía en la educaión dental: ¿Quo vadis? Int. J. Morphol., 28(1):71-73, 2010. 
RESUMEN: Los anatomistas comenzaron a familiarizarse con un debate sobre la integración de las ciencias básicas en el contexto clínico, o viceversa. Aunque diversas modalidades educativas en los programas de la escuela de odontología y estrategias del plan de estudios anatómicos han cambiado, las prioridades en la enseñanza de la anatomía y la emergencia de presentar los conceptos fundamentales para integrar los conocimientos de ciencias básicas de los estudiantes en la clínica de llevar a los educadores a desarrollar nuevos métodos de enseñanza. La búsqueda en la mejora de la eficiencia y el impacto de la presentación de los conocimientos a los estudiantes con el fin de originar en la evaluación una retroalimentación positiva debe ser una de las principales responsabilidades de los educadores en ciencias básicas. Los nuevos gold standarts, como herramientas informáticas de aprendizaje y laboratorios de instrucción asistida por computadora pueden ser los puntos gatillo para la percepción de la audiencia en las facultades de odontología. A la luz de estas consideraciones, la Sociedad Anatómica debe designar urgentemente perspectivas futuras.

PALABRAS CLAVE: Anatomía; Educación dental; Ciencias básicas.

\section{REFERENCES}

Azer, S. A. \& Eizenberg, N. Do we need dissection in an integrated problem-based learning medical course? Perceptions of first- and second-year students. Surg. Radiol. Anat., 29(2):173-80, 2007.

Brueckner, J. K. \& MacPherson, B. R. Benefits from peer teaching in the dental gross anatomy laboratory. Eur. $J$. Dent. Educ., 8:72-7, 2004.

Drake, R. L. Meeting the challenge: The future of anatomical sciences in medical school curricula. Anat. Rec. B. New Anat., 269:68, 2002.

Drake, R. L. A unique, innovative, and clinically oriented approach to anatomy education. Acad. Med., 82(5):4758, 2007.

Gregg, R. V. \& Fuller, P. M. A self-instructional approach to gross anatomy: evaluation of five years experience. $J$. Dent. Educ., 44(10):585-9, 1980.

Giffin, B. F. \& Drake, R. L. Gross anatomy of the head and neck and neuroscience in an integrated first-year medical school curriculum. Anat. Rec., 261(2):89-93, 2000.

Jones, N. A.; Olafson, R. P. \& Sutin, J. Evaluation of a gross anatomy program without dissection. J. Med. Educ., 53:198-205, 1978.
Klement, B. J.; Paulsen, D. F. \& Wineski, L. E. An anatomical backbone for an integrated first-year medical curriculum. FASEB J., 22:236, 2008.

McMenamin, P. G. Body painting as a tool in clinical anatomy teaching. Anat. Sci. Ed., 1(4):139-44, 2008.

Miller, S.; Perrotti, W.; Silverthorn, D. U.; Dalley, A. F. \& Rarey, K. E. From college to clinic: reasoning over memorization is key for understanding anatomy. Anat. Rec. B. New Anat., 269(2):69-80, 2002.

Nnodim, J. O. Learning human anatomy: by dissection or from prosections? Med. Educ., 24(4):389-95, 1990.

Pabst, R.; Westermann, J. \& Lippert, H. Integration of clinical problems in teaching gross anatomy: living anatomy, Xray anatomy, patient presentations, and films depicting clinical problems. Anat. Rec., 215(1):92-4. 1986.

Philip, C. T.; Unruh, P.; Lachman, N. \& Pawlina, W. An explorative learning approach to teaching clinical anatomy using student generated content. Anat. Sci. Educ., 1(3):106-10, 2008.

Sandra, A. \& Ferguson, K. J. Analysis of gross anatomy laboratory performance using a student dissection/ presentation teaching method. Teach. Learn. Med.,10(3):158-61, 1998.

Sinclair, D. C. An experiment in the teaching of anatomy. $J$. Med. Educ., 40:401-13, 1965.

Turney, B. W. Anatomy in a modern medical curriculum. Ann. R. Coll. Surg. Engl., 89(2):104-7, 2007.

Willson, J. T.; Tarby, T. J.; Seale, R. U. \& Whitlock, D. G.The two course system in gross anatomy. J. Med. Educ.,50(8):788-96, 1975.

Yeager, V. L. \& Young, P. A. Peer teaching in gross anatomy at St Louis University. Clin. Anat,. 5(4):304-10, 1992.

Correspondence to:

Dr. H. A. Balcioglu

Anatomi BD, Temel Bilimler AD

Dishekimligi Fakultesi

Istanbul Universitesi

Capa, 34390, Istanbul

TURKEY

Tel: +902124142020

E-mail: habalci@istanbul.edu.tr
Received: 10-06-2009 Accepted: 23-12-2009 
